\title{
Legal Basis Analysis of Imposition of Land and Building Tax with Tax Object Selling Value
}

\author{
Komang Febrinayanti Dantes ${ }^{1}$, I Gusti Ayu Apsari Hadi ${ }^{2}$ \\ \{febrinayanti.dantes@undiksha.ac.id ${ }^{1}$, apsari.hadi@undiksha.ac.id² \\ Universitas Pendidikan Ganesha, Indonesia ${ }^{1,2}$
}

\begin{abstract}
This study aims to determine the basics of tax imposition or calculation of the tax value on Land and Building Tax, with the Sales Value of Tax Objects in Buleleng Regency, and to determine the amount of land and building tax revenue in rural and urban areas (PBB-P2). This research is a type of legal research with empirical juridical studies, because this research deals with data. This research took place in Singaraja City, especially in the Regional Government Financial Management Agency Buleleng Regency. Data were collected using observation and interview methods. The data analysis was conducted in a descriptive qualitative manner. Based on the results of the analysis, the Buleleng Regency government has adjusted the tax object sale value on the land and building tax for rural and urban areas (PBB-P2). The adjustment of the tax object sale value rate is based on the amendment to Regional Regulation Number 5 of 2013, which was passed in 2018.
\end{abstract}

Keywords: Legal basis, Land, Building Tax

\section{Introduction}

Land and Building Tax are a mandatory levy taken by the government on a building used as a residence, company, and small and medium business actors. This land and building tax arises because of the economic benefits obtained by building owners, either as a residence or as a business. Land and Building Tax have an important role and great benefits for people's lives. The role of tax in a region is one of the revenues that can become a regional asset [1]. Taxes have two characteristics, namely taxes as income (budgeter) and regulation (nonbudgetary) [2]. Budgeter or what can be said as income, where taxes as regional income will later go into the regional treasury who will be managed by the regions for the development and welfare of rural and urban communities so that a just and prosperous society can be realized based on Pancasila and the 1945 Constitution.

The main philosophy that underlies taxes is the participation of the community in development and increasing the welfare and prosperity of the people through increasing state revenue by imposing taxes [3][4]. Land and Building Tax are a levy on land and buildings that arises because of the profit and / or socio-economic position of a person or entity that has a right on it, or obtains benefits from it[5]. When viewed from its nature, Land and Building Tax are a tax that is material in nature. That is, the amount of taxes payable are determined from 
the condition of the object, namely the land and / or buildings. Meanwhile, the condition of the subject does not determine the size of the goods.

In other words, Land and Building Tax are a state tax imposed on land and buildings, which has been regulated according to Law Number 12 of 1985 concerning Land and Building Tax (PBB) as amended to Law Number 12 of 1984. PBB Tax is a tax imposed on land and buildings, while the amount of land and building tax is determined by the condition of the object, namely land and building [6]. Land and building tax also has a material nature and the amount of taxes payable is determined by the condition of the land and building tax object. The earth is the surface of the earth and the body of the earth and what is under it[7].

As for the objects of the earth that must be paid PBB tax are rice fields, fields, gardens, land, yards, and mines. Whereas building objects according to the Buleleng Regency Regional Regulation Number 5 of 2013 Articles 3 number (2), namely environmental roads located in a building complex, residential houses, business buildings, multi-storey buildings, shopping centers, luxurious fences, swimming pools, toll roads, sports venues, shipyards, luxury parks, oil, water and gas reservoirs, and towers. The PBB tax base is a tax which is a source of state revenue, which is very significant in increasing and advancing development in a country, as well as for increasing the prosperity and welfare of its people. Therefore, the role of society is very important in terms of supporting governance.

The collection on PBB tax is based on Law Number 12 of 1994 concerning amendments to Law Number 12 of 1985 concerning Land and Building Tax. Then since the Enactment Of Law Number 28 of 2009 concerning Regional Taxes and Levies, the authority to collect land and building tax in the rural and urban sector (PBB-P2) has been transferred to the district / city government. With the issuance of the Buleleng Regency Regional Regulation Number 5 of 2013 concerning Rural and Urban Land and Building Taxes in Buleleng Regency, PBB tax is paid to the regions through the BPKPD of Buleleng Regency.

The regulations issued are specifically intended to provide direction for land or building appraisal to assist local governments in determining the Tax Object Selling Value (NJOP). This is important to do because if the tax calculation is incorrect, it will be detrimental to the Regional Government itself as the party that collects the tax. The rules set forth in the Guidelines for Earth and / or Building Assessments are included in the Regulation of the Minister of Finance (PMK) Number. 208 / PMK.07 / 2018. This rule is given so that local governments can accurately estimate NJOPs that are relevant and in accordance with field conditions and ideal market values.

Basically, each region has a different NJOP value, and this is often used as the basis for PBB tax. NJOP is the average price of a sale and purchase transaction which is determined based on a comparison of the prices of other similar objects. NJOP value can be determined through the following three aspects: Comparison of object price, new acquisition value, selling value of substitute tax objects, and calculation of NJOP value per / meter. The adjustment to the NJOP value in Buleleng Regency has an impact on the increase in the value of rural and urban PBB taxes (PBB-P2), and the increase is very fantastic.

So that the purpose of this study is to be able to provide an understanding of the increase in the value of PBB tax in Buleleng Regency so that it can be in accordance with the Land Value Zone (ZNT), and the public will increasingly know and understand the increase in accordance with Regional Regulation Number 5 of 2013. Then to describe what efforts can be 
made is made against the submission of objections by the public regarding the increase in the calculation of PBB and NJOP tax value.

\section{Method}

This research is about the analysis of the legal basis for the imposition of land and building tax on the tax object sale value (NJOP) in the Buleleng regency. The method used in this research consists of several parts, namely. This research is a type of legal research with feasible juridical studies, because this research is related to data, so this research is a practical lawful research [8]. Empirical legal research is the law adhered to by society. In this case, it is evident that the law is actually lived and used as a foundation by the community.

In research using the practical lawful method, lawful research is carried out to see the law in a real sense or the researcher can see how the law works in society. Empirical legal studies are studies that view law as a reality that includes social realities, cultural realities and others, not only examining law in books but also examining law in action [9]. This research aims to examine the lawful basis used in determining the increase in tax values in the Buleleng Regency area. How to calculate the Selling Value of the Tax Object so that it gets a value for calculating the value of the Land and Building Tax in Buleleng Regency.

This research took place in Singaraja City, Buleleng Regency, especially in the Regional Government Financial Management Agency of Buleleng Regency, which is located at Jalan Ngurah Rai No. 2 Singaraja. This research is based on preliminary considerations and observations that the researcher sees the number of complaints and objections made by the community in Buleleng Regency, so that the researcher feels new problems arise that can be minimized by referring to the rules apply permanently.

The data collection method used in this research study is by observation and interviews with the relevant local governments, in these case employees, officials and taxpayers in the Buleleng District Government Financial Management Agency. Literature / document studies are also related to the collection of primary legal materials consisting of several laws, government regulations, regional regulations that regulate rural and urban land and building taxes. The data processing and analysis techniques used in this study will be conducted qualitatively. The data that has been collected from the results of this study, both primary and secondary data, are processed and analyzed by methodically compiling these data. The data that has been arranged systematically are then linked to one another. After the data is linked, interpretation will be made to understand the meaning of the overall data collected. After going through a qualitative data analysis process, the data will then be presented in a descriptive qualitative and systematic manner [10].

\section{Results dan Discussion}

Buleleng Regency is one of the regencies in the province of Bali, which consists of 9 (nine) sub-districts, 19 (nineteen) wards, and 129 (one hundred twenty nine) villages. Based on the Regional Regulation of Buleleng Regency Number 14 of 2018 concerning Amendments to Regional Regulation 5 of 2013 concerning Rural and Urban Land and 
Building Taxes, the basis for the imposition of PBB-P2 is the Sales Value of Tax Objects hereinafter referred to as NJOP, which will be from the NJOP base value.

NJOP will be renewed every three years by the Minister of Finance and applied by the respective Regional Heads, however certain tax objects can be determined annually according to the development of each region. The determination of the NJOP of land and / or buildings is carried out through a process known as the appraisal process. This assessment is carried out solely to estimate the value of land and / or buildings as PBB objects. The value generated in the appraisal process will later be converted back into the classification of land and / or buildings. The result after the conversion takes place will become the classification of land and / or buildings and then determine the NJOP per square meter.

Referring to Law Number 28 of 2009 concerning Regional Taxes and Levies [11], the government provides the highest PBB-P2 tariff limit which is set at a maximum rate of $0.3 \%$. If seen from the figures, it can be interpreted that the effective tax rate is not high, and in the process of calculating the payable tax, it still receives a reduction in the form of Non-Taxable Selling Value (NJTKP). In the tax collection administration process, taxpayers / the public can submit complaints and objections if the tax determination is still high, and the accumulated nominal tax to be paid is too high. The NJOP, which is used as the basis for taxation of PBB$\mathrm{P} 2$, continues to adjust linearly from time to time and can be updated once every three years, by following several factors of development, growth and investment as well as buying and selling transactions in an area.

Since 2020, the PBB rate in Buleleng Regency which has been imposed has decreased, previously the rate imposed was $0.1 \%$ for tax objects with a Tax Object Selling Value (NJOP) below an IDR 1 billion. Meanwhile, for the NJOP of an IDR 1 billion and above reaches $0.2 \%$. Starting this year, tax imposition is divided into three groups, each $0.03 \%$ for NJOPs below IDR 1 billion, $0.08 \%$ for NJOP starting from IDR $1-5$ billion and $0.05 \%$ for NJOP above the IDR 5 billion. The local government has adjusted the NJOP to the current conditions. The NJOP adjustment affects the nominal tax to be paid. A number of people who before the increase paid taxes of IDR 300,000, (three hundred thousand rupiah), but with this increase, it becomes IDR 1,800,000, (one million eight hundred thousand rupiah). This high increase can also be burdensome to the community, especially with the pandemic conditions that occur globally.

BPKPD (Regional Tax Financial Management Agency) collaborates with the Ministry of Finance's Directorate General of State Assets in determining NJOP that is in accordance with the prevailing market price. The elements of consideration that are used as a benchmark in tax imposition are electricity, water bills and also the location of the tax object itself. Taxpayers can submit objections during the filing period determined by BPKPD Buleleng Regency. There are two types of objections submitted by taxpayers, the first objection can be submitted directly to the BPKPD of Buleleng Regency. The second objection can be submitted collectively through the village apparatus. The government, in this case the Buleleng Regency Regional Tax Financial Management Agency, continues to consider the objections raised by the public / taxpayers. As it is known, in 2019 the Buleleng Regency Government distributed 202.188 SPPT sheets, with a tax assessment value of an IDR 40,4 billions. For this year, BKD Buleleng has set a PBB realization target of an IDR 24.13 billions. Until now, the realization of the potential for PBB-P2 has reached an IDR 3.21 billion.

As for some of the Legal Basis for Land and Building Tax (PBB), among others 
1) Law No. 12 of 1985 as last amended by Law No. 12 Year 1994 on Land and Building Tax.

2) KMK No. 201 / KMK.04 / 2000 concerning Adjustment of the Sales Value of NonTaxable Tax Objects as the Base for Calculating Land and Building Tax.

3) KMK No. 523 / KMK.04 / 1998 concerning Determination of Classification and Amount of Selling Value of Tax Objects as the Basis for Imposing Land and Building Tax.

4) KMK No. 1004 / KMK.04 / 1985 concerning the determination of bodies or representatives of international organizations that use objects of land and building tax that are not subject to land and building tax.

5) Decree of the Director General of Taxes Number: KEP-251 / PJ. / 2000 concerning Procedures for Determining the Amount of Sale Value of Non-Taxable Tax Objects as the Base for Calculating Land and Building Tax.

6) Decree of the Director General of Tax's numbers: KEP-16 / PJ.6 / 1998 concerning Imposition of Land and Building Taxes Circular of the Director General of Taxes Number: SE-43 / PJ.6 / 2003 concerning Adjustments of the Amount of the Sale Value of NonTaxable Tax Objects (NJOPTKP PBB and Changes in the Value of the Acquisition of Non-Taxable Tax Objects (NPOPTKP) BPHTB for the 2004 fiscal year.

7) Circular of the Director General of Taxes Number: SE-57 / PJ.6 / 1994 concerning Confirmation and Explanation of PBB Exemption for Public Facilities and Social Facilities for Industrial Estates and Real Estate.

Regulation of the Minister of Finance of the Republic of Indonesia Number 208 / PMK.07 / 2018 concerning Guidelines for Assessing Rural and Urban Land and Building Taxes. In the imposition of the value of Land and Building Tax based on the value of the object, every taxpayer / community that has fulfilled subjective and objective requirements in accordance with the taxation legislation is obliged to register, record the place and position of taxpayers, individuals and entities. The subjective requirements of PBB P-2 are individuals / bodies that in actual / real terms have rights over the land and / or receive benefits over the land, and / or own, control and / or benefit from buildings. In addition to subjective requirements, the assessment of taxation can also be carried out by fulfilling objective requirements in the form of an assessment based on the place and position of the taxpayer listed in their ownership, except for areas used for plantation, forestry and mining business activities.

Based on the prevailing regulations, the basis for imposition of PBB P-2 tax is to refer to the NJOP value which can be renewed every three years by referring to the Regulation of the Minister of Finance, thus the Sales Value of Tax Objects is in accordance with developments in market prices in the community. The government, through the tax authorities, is functioning in determining, issuing and preparing PBB P-2 Tax Return (SPPT) for taxpayers. However, the community as taxpayers can always play a functioning role by reporting their tax objects that have not been registered / registered or have undergone a change / transfer of function, so that the government and society can be in harmony with carrying out their obligations for the common good. According to data from BPKPD Buleleng, Regional Revenue in 2020 was previously targeted at IDR $2,320,776,327,656$. At the same time, after the pandemic and loss occurred in a number of income sectors, the target was corrected and decreased by 16.61 percent of the 2020 Buleleng APBD to become IDR 1,935,359,380,373. 
The determination of the Tax Object Selling Value (NJOP) as the basis for the imposition of Rural and Urban Land and Building Tax (PBB P-2) is carried out by an assessment. Sales Value of Tax Objects (NJOP) is the average price obtained from sale and purchase transactions that occur fairly, and if there is no sale and purchase transaction, the Sales Value of Tax Objects can be determined by comparing prices with other similar objects new acquisition or replacement NJOP. The Selling Value of Tax Objects includes the selling value of the earth's surface (land, waters, interior, and sea of the regency / municipal territory) and / or the building attached thereon.

The basis for the imposition of land and building tax, namely, (Article 6 of Law No. 12 of 1985. Law No. 12 of 1994 in conjunction with Article 2 (3) KMK-523 / KMK.04 / 1998) which is the basis for imposition PBB is the Sales Value of Tax Objects (NJOP). The amount of the Sales Value of Tax Objects is determined every three years by the Minister of Finance, except for certain regions, which is determined annually in accordance with regional developments. Determining the NJOP value as the basis for imposition of Land and Building Tax in accordance with the Decree of the Minister of Finance No. 523 / KMK.04 / 1998, are grouped into group A and group B. Tax objects whose selling value per M2 is greater than the provisions for the Sales Value of Tax Objects occurring in that field are used as the basis for imposition of Land and Building Tax. In general, the amount of taxes payable are calculated by multiplying the tax rate by the taxable sale value (NJKP) in accordance with Article 7 of Law No. 12 of 1985. Law No. 12 of 1994, the amount or percentage of the Taxable Sales Value (NJKP) has been stipulated by a Government Regulation by taking into account the condition of the national economy.

The NJOP tariff adjustment is a follow-up to the amendment to Perda No. 5/2013 concerning PBB-P2. In this adjustment, the Buleleng Regency Government through the Regional Financial Agency (BKD), has hired an appraisal team to calculate the change in the NJOP PBB-P2 rate. Now, these tariff adjustments are starting to take effect for PBB P2 in 2019. Determination of the Sales Value of Tax Objects is not far from the mapping of land zone values. Land value zones are determined by the results of surveys conducted by the National Land Agency (BPN) as well as consideration of market prices and field location's land factually. The purpose of making a Land Value Zone is to provide information on land used in land services. The Land Value Zone (ZNT) is an area that describes the land value that is relatively the same from a set of land parcels in it. The boundaries are imaginary or nata according to land use and have differences value between one another based on comparative analysis of market prices and costs. Meanwhile, a land value zone map is a map depicting a geographical zone consisting of a group of land parcel rights objects which have one average value (NIR) which is limited by the limits of control / ownership in a village and sub-district administrative area.

\section{Conclusion}

The Buleleng Regency Government has adjusted the tax object sale value (NJOP) on the land and building tax for rural and urban areas (PBB-P2). As a result, the PBB-P2 bill in the taxpayer notification letter (SPPT) for the 2019 period will increase. The adjustment of the tax object sale values rate (NJOP) is based on the amendment to Regional Regulation (Perda) Number 5 of 2013, which regulates Rural and Urban Land and Building Tax (PBB-P2) which 
was passed in 2018. "PBB-P2 tariff will increase. The increase in NJOP for land owners in an area of less than 1 hectare will not be too significant. On the other hand, for owners of hectares, the increase will be felt. If you only have 2 hectares of land, the increase will just be IDR 5,000." Sales Value of Tax Objects (NJOP) is the average price obtained from sale and purchase transactions that occur fairly, if there is no sale and purchase transaction, the sale value of the tax object (NJOP) is determined through a price comparison with other similar objects, the new acquisition value or a substitute. Each Regional Head determines the Tax Object Sales Value (NJOP) every 3 (three) years in accordance with the Minister of Finance Regulation. The process of determining the value of the NJOP amount on land and / building is through the appraisal process by the appointed appraisal. The value generated in the appraisal process will then be converted into the classification of land and / or buildings. These results are used as the basis for classifying land and / or buildings so that the amount of the Tax Object Selling Value per square meter can be determined. Land and Building Tax (PBB P-2).

\section{References}

[1] F. Is, "Peranan Pajak Daerah dan Retribusi Daerah Pada Dinas Pendapatan Pengelolaan Keuangan dan aset Kabupaten Rokan Hulu," J. Ilm. Cano Ekon., vol. 2, no. Pajak Daerah dan Retribusi Daerah, pp. 59-71, 2013.

[2] N. Andriani, "Andriani, N. (2017). Eksistensi Pengaturan Pajak Daerah Dalam Meningkatkan Pendapatan Asli Daerah Di Pemerintah Provinsi Jawa Tengah," UNNISULA, 2017.

[3] I. Waani, "Analisis Efektivitas Dan Kontribusi Pajak Air Permukaan Terhadap Penerimaan Pendapatan Asli Daerah Provinsi Sulawesi Utara," J. Ris. Ekon. Manajemen, Bisnis dan Akunt., vol. 4, no. 1, pp. 667-675, 2016.

[4] D. Sulastyawati, "Hukum Pajak dan Implementasinya Bagi Kesejahteraan Rakyat," J. Sos. dan Budaya Syar-i, vol. 7, no. 10, pp. 119-128, 2020.

[5] M. P. P. Parahita, S. Nahak, and I. K. Widia, "Criminal Sanctions against Taxpayer Who are Negligent to Register Land and Building Taxes," J. Huk. Prasada, vol. 7, no. 2, pp. 73-78, 2020.

[6] R. M. Elfiza, “Rani Maria Elfiza,” Lampung, 2016.

[7] R. Almy, "Valuation and Assessment of Immovable Property," OECD Work. Pap. Fisc. Fed., no. 19, pp. 0_1,2,5-26, 2014.

[8] P. M. Hadjon, Pengantar Hukum Administrasi. Yogyakarta: Gadjah Mada University Press, 2005.

[9] A. Ali and W. Heryani, Menjelajahi Kajian Empiris Terhadap Hukum. Jakarta: Kencana Prenada Media Group, 2012.

[10] J. Ibrahim, Teori dan metodologi penelitian hukum normatif, vol. 57. Malang: Bayumedia Publishing, 2006.

[11]R. I. Undang-Undang, Nomor 28 Tahun 2009 Tentang Pajak Daerah dan Retribusi Daerah. 2010. 